\title{
Birth Characteristics and Pre-Weaning Lamb Growth of Grazing Sudan Desert Ewes Supplemented in Different Reproductive Stages
}

\author{
Omer Mohammed Bushara, Salih Ahmed Babiker, Ikhlas Ahmed Nour, and Omer Mustafa Osman
}

\section{ABSTRACT}

This work was conducted to study effect of supplementary feeding at different reproductive stages on birth characteristics and pre weaning growth performance of lamb born to desert sheep (Hamari subtype) raised on natural range in West Kordofan State, Sudan. Ninety ewes of similar age and live weight were used in the study. Ewes were divided into three feeding group of 30 animals each. Group A was given concentrate supplement for one month before mating, one month during mating, and one month before lambing; group $B$ was given the supplement for one month during mating and one month before lambing, while group $C$ was left as a control group kept on natural grazing. The concentrate diet consisted of sorghum grains $15 \%$, groundnut cake $20 \%$, molasses $15 \%$, wheat bran $25 \%$, groundnut hulls $23 \%$, salt $1 \%$ and $1 \%$ limestone, and was offered at a rate of $500 \mathrm{gm}$./ewe/day. All animals were allowed to graze on natural range and were watered every 2-3 days. The result indicated that birth weight in general and that of ram lambs was heavier in concentrate supplemented ewes. Although there was no significant difference between supplemented and grazing ewes on pre-weaning growth rate of their lambs yet lambs born to non-supplemented ewes had lower total live weight gain. It is recommended that feed supplementation and range improvement programs are needed as water harvesting and reseeding of range lands to reduce stress of long journies searching for water and forage, to improve productive performance of sheep and preweaning growth of their lambs.

Keywords: Supplementary feeding, pre weaning, growth performance, Hamari sheep, Sudan.

\section{INTRODUCTION}

Sheep of Sudan are of great economic importance and are bred mainly for meat production, providing all lamb and mutton for local consumption, as well as live animals, lamb, mutton and skin for export. Sheep population of Sudan amount to $40.2 \%$ million heads which represent $40 \%$ of livestock of the country. The main type of the Sudan sheep population is the desert sheep which represent $86 \%$ of the sheep found in the country. Hamari and Kabashi are the main desert sheep eco-types found in western Sudan states Darfur and Kordofan. The western part of the latter state holds about 4.21 million head [1]. Sheep of the Sudan are mainly raised by traditional producers and the flock size in Kordofan state varies from 56 head in small flocks to 403 head in large flocks [2]. Sheep flocks in these states are well adapted to nomadic conditions with traditional management practices, and thrive on low quality range grasses, high ambient temperature and water scarcity, during summer season that reduce their production potential [3], [4]. The annual off take number of sheep in 2016 was about 20.461 thousand head which represented $90 \%$ of total livestock exports of the country[1]. Dry season supplemented feeding
Submitted : November 30, 2020

Published : February 23, 2021

ISSN: $2684-1827$

DOI: $10.24018 /$ ejfood.2021.3.1.189

Omer Mohammed Bushara *

Department of meat production, Faculty of Animal Production, Alkhuway, West Kordofan University, Sudan.

(e-mail: omerboshara@ ${ }^{\text {gmail.com) }}$ Salih Ahmed Babiker

Department of Meat Production, Faculty of Animal Production, University of Khartoum, Khartoum North, Sudan. (e-mail: Abusalih40@gmail.com) Ikhlas Ahmed Nour

Department of Meat Production, Faculty of Animal Production, University of Khartoum, Khartoum North, Sudan. (e-mail: Iklas-nour@yahoo.com) Omer Mustafa Osman

Desert sheep research station, Ministry of Animal Resources and Fisheries, West Kordofan state, Al Nohood, Sudan. (e-mail: omerboshara@gmail.com)

*Corresponding Author

is recommended to alleviate nutritional stress and production loss[5], [6].

\section{MATERIAL AND Methods}

\section{A. Study Site}

This study was conducted at Elnuhood Locality, West Kordofan State, Sudan. The Location lies between latitudes $(12-14)^{\circ}$ north and longitudes (27-30) ${ }^{\circ}$ East. The area is located within the poor Savannah belt. The climate is warm in the wet season and hot dry in summer, with a temperature range $11{ }^{\circ} \mathrm{C}$ to $46{ }^{\circ} \mathrm{C}$. The rainy season lasts for four months (July to October) and the annual average rainfall is between 450-550 $\mathrm{mm}$.[ 7].

The soil nature is mostly stabilized sand dunes and smooth undulating sandy plains (Goz) of low fertility and capable of absorbing all the rainfall water, and is consisting of yellowish red sandy loam, dissected by batches of loamy clay soils (Gardood or Gurraba) in the southern part [8]. The ecological zone in the area is mainly determined by rain fall and subdivisions are mostly depending on soil type and vegetation. The dominant vegetation is a variable mixture of thorny trees, shrubs, herbs, and grasses. The 
Acacia trees are dominant in the area where Acacia senegal (Hashab) is the most important type from an economic point of view, as it produces Gum Arabic which is considered as the best cash crop. Other trees include Acaia albida (Haraz), Bascia senegalensis (Mokhait), Sclerocarya birrea (Hummait), Guiara aengegalensis (khubaish), Albizza amara (Arad), Adansonia digitata (Tabldi), Terminalia brownie (Daroot) and Combretum cordofanum (Habiel). The Grasses and herbs which predominate include Dactyloctinium aegyptiun (Abu- Asabi), Echnochloa colonum (Difra), Andropogon gayanus (Abu Rakhies), Zornia glockidata (Shiline), Aristida mutablis (Gaw), and Ipomea cordiosepala (Tabar). Overgrazed areas are dominated by less palatable species such as Eragrostis tremula (Banu), Cenchrus biflorus (Haskaneet), Calotropis procera (ushar), grasses and herbaceous species such as Cenchrus setigrus, Chloris gayana, Cassia acutifolia Alexandrian (Senna), and Abutilon spp (El Neiada).

\section{B. Experimental Ewes}

The study involved ninety local Sudanese desert ewes (Hamari subtype) of similar age (1-2 permanent incisors), and average weight range (40 to 58$) \mathrm{Kg}$. The animals were introduced to a concentrate diet which is shown in Table I over 15 days before the start of the experiment during which they were treated with Ivomec against internal and external parasites and drenched with Albendazole. Thereafter ewes were divided according to supplement feeding into three groups designed as (A), (B) and (C). Each group consisted of 30 animals of equal weight and age. Five Mature rams with (1-3) permanent incisors and an average weight of $60-100 \mathrm{~kg}$ were introduced to the experimental ewes at the beginning of the mating period.

Animals were allowed to graze together during the day in the surrounding grazing pastures. Supplementation with the concentrate diet was given during the breeding period which started in February and continued to March, at a rate of 500 gram/ewe/day. The supplement was offered on group base during the resting period when ewes returned from grazing (sarba) shortly before sun rise. Feed supplement was distributed at random among ewe groups. Group (A) was given the supplement for one month before, and one month following joining of rams with ewes, and also for one month before lambing which was during the rainy season (June), Group (B) was given the supplement for one month before joining of rams with ewes, and one month before lambing, whereas group (C) remained as a control group which was kept on natural grazing only. Animals were watered every 2-3 days according to ambient temperature.

Lambs born to the different ewe groups were used in this study. Newly born lambs were separated from their dams in the early morning and kept in an enclosure built from tree branches under big trees. Lambs were allowed to graze near herder's residence locally called (Morahh) to allow careful observation and protection from high temperature. Ewe flocks were grazed away from herder's residence up to midday when they returned to nurse their lambs. At the age of 4-6 weeks lambs were allowed to graze with their dams. Lambs suckled their dams freely until weaning at the age of 12 weeks. Pre-weaning growth performance was determined by weighing lambs soon after birth and then every two weeks until weaning. Lambs mortality was recorded.

TABLE I: INGREDIENT PROPORTIONS AND CHEMICAL COMPOSITION OF

\begin{tabular}{cc} 
THE CONCENTRATE DIET & \\
\hline Ingredients & $\%$ \\
\hline Sorghum grains & 15 \\
Groundnut cake & 20 \\
Molasses & 15 \\
Wheat Bran & 25 \\
Groundnut Hulls & 23 \\
Salt & 1 \\
Limestone & 1 \\
Total & 100 \\
Chemical composition & $\%$ \\
Dry matter & 95.15 \\
Crude protein & 18.51 \\
Crude fiber & 7.57 \\
Ether extract & 4.65 \\
Ash & 8.10 \\
Nitrogen Free Extract & 61.27 \\
Calculated Crude Protein $(\mathrm{CP}) \%$ & 18.47 \\
Calculated Metabolizable Energy (MJ/kg) & 10.7 \\
\hline
\end{tabular}

During the study period lambs were treated with Ivomec and drenched with Albendazol against external and internal parasites. Lambs were also vaccinated against diseases as sheep pox, and PPR which are endemic in the area. Oxytetracycline at a dose of $1.5 \mathrm{cc}$ per animal was administrated to all animal as a broad spectrum antibiotic. Clinical signs of pneumonia when observed were treated with injections of (Tylosin) at a rate of $1.5 \mathrm{cc} / \mathrm{head}$. Cases of blindness and severe diarrhea were observed and treated with drops of a mixture of Dexaphan and Oxytetracycline at a ratio of $3: 1$.

\section{Production Parameters Data}

Within 24 hours of birth, date of birth, birth weight, type of birth, sex of lamb and number of lambs born per ewe were recorded. A bascule Balance $(0-100 \mathrm{~kg})$ was used for weighing. Lamb weight gain, pre-weaning growth rate, and weaning rate were calculated according to [9]. Weaning age and weight were recorded and mortality rate was also calculated.

\section{Statistical Analysis}

The data were subjected to analyses of variance applicable to simple randomized design [10] using the software package (SPSS version 11.50 2002).

\section{RESULTS}

\section{A. Effect of Concentrate Supplementation of Hamari Ewes on Birth Characteristics}

The effect of concentrate supplementation on lamb birth weight, and type of birth presents in Table II. Ewes in group (A) had greater birth rate than those in the other groups. Birth rate was $107.67 \%$ in group (A) and was $100 \%$ in both group (B) and (C). Ewes in group (A) had a twin's rate of $7.7 \%$ while those in group (B) and (C) had single births only. Mean birth weight was not significantly different between the three groups; however, ewes in group (A) had slightly lower mean birth weight. Male and female lamb's birth weights were not significantly different between ewes groups, yet ewes of group (A) had slightly lower birth 
weight for both male and female lambs than ewes of group (B) and (C). Between sexes male lambs in all treatments had heavier birth weight than females.

TABLE II: EFFECT OF CONCENTRATE SUPPLEMENTATION OF HAMARI EWES ON BIRTH CHARACTERISTICS

\begin{tabular}{|c|c|c|c|c|c|}
\hline \multirow{2}{*}{ Birth rate } & \multicolumn{3}{|c|}{ Ewe Group } & \multirow{2}{*}{ SE } & \multirow{2}{*}{$\begin{array}{c}\mathrm{P} . \\
\text { Level }\end{array}$} \\
\hline & $\mathrm{A}$ & $\mathrm{B}$ & $\mathrm{C}$ & & \\
\hline Birth rate $(\%)$ & 107 & 100 & 100 & ND & ND \\
\hline Single rate $(\%)$ & 92.30 & 100 & 100 & ND & ND \\
\hline Twins rate $(\%)$ & 7.70 & 0.00 & 0.00 & ND & ND \\
\hline Male birth rate $(\%)$ & 65.38 & 65.00 & 55.56 & ND & ND \\
\hline Female birth rate $(\%)$ & 42.31 & 35.00 & 44.44 & ND & ND \\
\hline $\begin{array}{l}\text { Mean birth } \\
\text { weight }(\mathrm{kg})\end{array}$ & 4.50 & 4.81 & 4.71 & 0.11 & NS \\
\hline $\begin{array}{l}\text { Male birth } \\
\text { weight }(\mathrm{kg})\end{array}$ & 4.64 & 5.06 & 4.93 & 0.13 & NS \\
\hline $\begin{array}{l}\text { Female birth } \\
\text { weight }(\mathrm{kg})\end{array}$ & 4.28 & 4.31 & 4.44 & 0.17 & NS \\
\hline
\end{tabular}

NS: Not significantly different. ND: No Data.

B. Effect of Concentrate Supplementation of Hamari Ewes on Pre-weaning Growth Performance of Their Lambs

The effect of concentrate supplementary feeding of ewes on pre- weaning growth performance of their lambs presents in Table III. The results revealed no significant $(\mathrm{P}<$ 0.05 ) differences among the three treatments (A, B, and $\mathrm{C}$ ). A shown in Table IV and Figure 1 there were no significant $(\mathrm{p}<0.05)$ differences in lamb daily weight gain in the pre weaning intervals among the different concentrate supplemented ewes. However, daily weight gain was continuously lower up to day 90 post-partum in lambs born to ewes left on natural grazing compared with those given concentrate supplementations. Similarly, total pre weaning live weight gain was lower in those lambs born to ewes of the former group compared with those given supplementary feeding.

TABLE III: EFFECT OF CONCENTRATE SUPPLEMENTATION OF EWES ON PRE-WEANING GROWTH PERFORMANCE OF THEIR LAMBS (KG)

\begin{tabular}{|c|c|c|c|c|c|}
\hline \multirow{2}{*}{ Live weight (kg) } & \multicolumn{3}{|c|}{ Lamb Group } & \multirow{2}{*}{ SE } & \multirow{2}{*}{$\begin{array}{c}P . \\
\text { Level }\end{array}$} \\
\hline & $\mathrm{A}$ & $\mathrm{B}$ & $\mathrm{C}$ & & \\
\hline Birth Weight & 4.50 & 4.80 & 4.71 & 0.11 & NS \\
\hline 15 days & 9.21 & 9.37 & 9.23 & 0.16 & NS \\
\hline 30 days & 12.25 & 12.89 & 12.19 & 0.21 & NS \\
\hline 45 days & 15.54 & 15.97 & 15.32 & 0.29 & NS \\
\hline 60 days & 18.25 & 18.89 & 18.00 & 0.35 & NS \\
\hline 75 days & 20.23 & 20.82 & 19.76 & 0.37 & NS \\
\hline 90 days & 21.58 & 22.42 & 20.79 & 0.37 & NS \\
\hline 105 days & 22.75 & 23.29 & 21.79 & 0.37 & NS \\
\hline 120 days & 24.14 & 24.37 & 23.15 & 0.37 & NS \\
\hline
\end{tabular}

TABLE IV: EFFECT OF CONCENTRATE SUPPLEMENTATION OF HAMARI EWES ON PRE-WEANING DAILY WEIGHT GAIN OF THEIR LAMBS (G)

\begin{tabular}{|c|c|c|c|c|c|}
\hline \multirow{2}{*}{ Items } & \multicolumn{3}{|c|}{ Lamb Group } & \multirow{2}{*}{ SE } & \multirow{2}{*}{$\begin{array}{c}\text { P. } \\
\text { Level }\end{array}$} \\
\hline & $\mathrm{A}$ & $\mathrm{B}$ & $\mathrm{C}$ & & \\
\hline $\begin{array}{c}\text { Number of } \\
\text { lambs }\end{array}$ & 26 & 19 & 18 & ND & ND \\
\hline 15 days & 307.33 & 296.67 & 282.67 & 0.16 & NS \\
\hline 30 days & 202.67 & 234.67 & 186.00 & 0.23 & NS \\
\hline 45 days & 219.33 & 205.33 & 198.00 & 0.17 & NS \\
\hline 60 days & 180.67 & 195.33 & 168.67 & 13.00 & NS \\
\hline 75 days & 132.00 & 134.67 & 111.33 & 0.11 & NS \\
\hline 90 days & 94.67 & 110.67 & 64.00 & 0.13 & NS \\
\hline 105 days & 79.33 & 58.00 & 62.67 & 0.11 & NS \\
\hline 120 days & 98.00 & 72.00 & 85.33 & 0.08 & NS \\
\hline $\begin{array}{c}\text { Total pre. } \\
\text { Wt. gain(kg) }\end{array}$ & 19.55 & 19.45 & 17.40 & 0.47 & NS \\
\hline $\begin{array}{c}\text { Average daily } \\
\text { wt. gain }(\mathrm{g})\end{array}$ & 162.92 & 162.08 & 145.00 & ND & NS \\
\hline
\end{tabular}

ND: No Data. Pre: Pre-weaning. Wt.: Weight.

\section{DISCUSSION}

Birth weight is one of the important parameters in animal production especial meat production. Young animals which have heavier birth weights tend to have best life start and rapid growth following pre and post weaning period [11], [12]. The results of this study indicated that there was no significant $(\mathrm{P}<0.05)$ difference in mean birth weight between groups. However, concentrate supplemented ewes of group (A) recorded the lowest mean birth weight of 4.50 $\mathrm{kg}$, compared with group (B) which recorded the highest birth weight of $4.81 \mathrm{~kg}$, followed by the control group which recorded $4.71 \mathrm{~kg}$. The low birth weight in group (A) could possibly be due to their twin's rate. In addition, seventy six percent of ewes in group (A) got served during the first and second heat, while ewes in group (B) and (C) which were served during the first and second heat were 50 $\%$ and $46 \%$ respectively. That meat great number of ewes in group (A) became late pregnant during the unfavorable conditions of the range land (increase of ambient temperature, drying of surface water sources, and deterioration of vegetation), which forced ewes to travel long distances in search of feed and water. These stressful conditions reflected negatively in their general body status and fetal growth. Reference[13] indicated that eighty percent of fetus growth occurred during the latest 60 days of pregnancy, which required increased nutrient level of ewes. Reference [14] reported that feed supplementation to pregnant ewes during late gestation supported embryonic and fetus growth and maintained animal physiological needs. The current result agreed with reference [6] who found that inadequate feed intake during late pregnancy caused a reduction in birth weight. Also reference [5] found that in Sudan birth weight was significantly higher $(\mathrm{P}<0.05)$ in lambs born to dams that received supplement, watered daily and rested under shade. Similarly reference[15] reported that supplementation to grazing ewes on pasture improved their body weight at mating, reproductive performance, and birth weight increased significantly $(p<0.001)$. On the other hand, reference [16] found no significant differences between birth weights of supplemented and non-supplemented grazing Awassi ewes. These ewes possibly were on good grazing pasture. The current study showed that overall birth weight ranged from 4.80 to $4.71 \mathrm{~kg}$, which was heavier than that reported by references [17] for Sudan desert sheep (2.50 to $4.20 \mathrm{~kg}$ ). However, this result was also in line with reference [18] who reported a mean birth weight of Hamari lamb as 4.38 $\mathrm{kg}$.

The current study revealed that there was no significant $(\mathrm{P}<0.05)$ difference in birth weight between sexes, but tended to be higher in males, which agreed with [19], [20] and [5].

Birth and twins' rates were higher in dams of group (A) that were concentrate supplemented pre and post mating than those of the other ewes groups. This could possibly be due to improved ovulation and fertilization by supplementation. Reference [21] reported that flushed and steamed-up Sudan desert ewes had higher birth and twins' rates.

The effect of concentrate supplementation of ewes on pre-weaning growth performance of their lambs up to 120 
days of age demonstrated no significant $(\mathrm{P}<0.05)$ differences in daily weight gain between the different concentrate supplemented groups but lambs born to concentrate supplemented ewes had higher pre-weaning growth rate and heavy weaning weights than lambs born to ewes left grazing natural pasture only. Pre-weaning growth is affected mainly by dam milk yield. References [22], [23] reported that the genetic potential of the ewe, mothering ability and milk yield of ewes determined the pre weaning growth of lamb. Lack of significant differences in ewe milk yield could possibly explain lack of differences in preweaning growth. However, deterioration of pasture could explain the low pre weaning growth of lambs born to dams left on grazing only.

This result agreed with References [9], [20]who found that concentrate supplementation given to ewes improved lambs growth rate before weaning (0-120) day, and lambs born to supplemented ewes had heavier body weight than those suckled on non-supplemented ewes. References [24], [25] also reported that sheep raised under traditional systems suffer serious seasonality in feed supply both in quantity and quality especially during dry summer months when animals could hardly secure enough feed to maintain themselves.

The result of the present study indicated that there were no significant $(\mathrm{p}<0.05)$ differences in daily weight gain during the pre-weaning period $(0-120)$ day. Pre weaning weight gain of lambs was lower in lambs born to ewes left on natural grazing compared with those born to ewes given supplementary feeding. Pre-weaning weight gain of lambs born to ewes left on natural grazing was $17.40 \mathrm{~kg}$, and their average daily gain was $145 \mathrm{gm}$., which was lower compared with those born to ewes of group (A) and (B) that were given concentrate supplementation and gained 19.45 and $19.55 \mathrm{~kg}$ and had an average daily gain of 162.92 and $162.08 \mathrm{gm}$. respectively.



Fig. 1. Effect of concentrate supplementation of Hamari ewes on pre weaning daily weight gain of their lambs $(\mathrm{g})$.

Similarly, [26] reported an average pre-weaning weight gain of 19.95, and $19.76 \mathrm{~kg}$ for Hamari and Kabashi sub types respectively, and he found that pre-weaning average daily gain of desert lambs, Dubasi subtype was $187 \mathrm{gm}$. /day, while Reference [27] reported pre-weaning average daily gain of $152 \mathrm{gm}$. /day for Sudan desert lambs.

\section{CONCLUSION}

It can be concluded from that concentrate supplementation of grazing ewes improved their birth weight and lamb pre-weaning growth rate. Thus, improvement of the nutrition condition of ewe through concentrate supplementation or pasture improvement and water availability in arid hot zones in essential to enhance lamb productivity.

\section{ACKNOWLEDGMENT}

My gratitude and appreciated to Director of instituted for Study and Promotion of Animal Exports, University of Khartoum, and especially grateful thanks are extended to Director of Al Nohood Desert Sheep Research Station, Ministry of Animal Research and Fisheries, West Kordofan state for providing sheep for the study and their encouragement. Thanks are also extended to the technical staff of Meat production Laboratories, Faculty of Animal production, University of Khartoum for technical assistance. My sincere thanks to my friends for their nonstop assistant during this work.

\section{REFERENCES}

[1] Ministry of Animal Resources and Fisheries, M. A. R.F. General Administration for Planning and Animal Resources Economics, Khartoum, Sudan. 2014, 2017.Website https://www/info@mar.gov.sd. [accessed 09 2018].

[2] O. Bushara, S. Babiker, O. Mustafa, and A. Abed Alraheem (2019). Effect of Concentrate Supplementation of Lambs Born to Concentrate Supplemented Ewes under Range Conditions of Sudan. Journal of Animal Husbandry and Dairy Science. Vol 3(4) pp 12-17.

[3] F. El Hag, Effect of chopping and wilting on Tropical grassland silage quality in south Kordofan. African Livestock Research1992: Vol 2: $11-14$.

[4] A. Idris, F. El-Hag, C. Kijora, A. Salih. I. Bushara. Effect of dietary supplementation on reproductive performance of Sudanese Desert sheep, Conference on International Research on Food Security, Natural Resource Management and Rural Development. Tropentag. University of Bonn, Germany, 2011. https://www.researchgate.net/publication/311825975.

[5] S, Bukhari. Effect of management and feed supplement on performance, fertility and carcass characteristics of Sudan desert sheep raised under range conditions. Ph. D, Faculty of Animal production, University of Khartoum, 2011.

[6] A. Idris, C. Kijora, F. El-Hag, A. Salih, S. Fadul Elmola. Climate change adaptation strategies for sheep production in range land of Kordofan Region. The World Essays Journal 2014 Vol: 1 (1): 20-25, Available online at https://www.worldessaysj.com.

[7] El Nuhood Meteorological Station, Seasonal rainfall records. Sudan (2015).

[8] M. Harrison, J. Jackson. Ecological classification of the vegetation of the Sudan. Forest Bulletin 2:45. Agriculture Publications Committee, Forest Department, Ministry of Agriculture, Khartoum, Sudan, 1958.

[9] E. Landais, M. Cissoko. Methodological bases for measuring animal performances pp 433-485. IEMVT/ISRA, 1986.

[10] R. Steel, J. Torrie. Principles and Procedures of Statistics A biometrical approach, 2nd Edition, McGraw-Hill Book Company, New York. U.S.A. 1980.

[11] A. Allama. Some productive and reproductive traits in Sudan desert sheep. M Sc., Faculty of Animal Production, University of Khartoum, 1987.

[12] A. Sulieman, A. Sayers, T. Wilson. Evaluation of Shugor, Dubasi and Watish subtypes of Sudan Desert sheep at El-Huda National Sheep Research Station, Gezira Province Sudan, International Livestock Research institute: Report No. 18, ILRI publications [377], Addis Ababa, Ethiopia. 1990

[13] L. Dawson, A. Carson, D. Kilpatrick. The effect of the digestible un degradable protein of concentrates and protein source offered to ewes 
in late pregnancy on colostrum production and lamb performance. Animal Feed Science and Technology 1999, 82, 21-36. https://doi.org/10.1079/ASC40890101.

[14] N. Oeak, M. Cam, M. Kuran. The effect of high dietary protein levels during late gestation on colostrum yield and lamb survival rate in singleton bearing ewes. Small Ruminant Research 2005: Vol: 56, 8994.

[15] A. Njoya, N. Awa, J. Chupamon. The effect of Strategic Supplementation and prophylaxis on the reproductive performance of prim parous ewes in semi-arid area zone of Cameroon. Small Ruminant Research 2005: Vol: 56:21-29. doi 10.1016/S09214488(03)00010-5.

[16] Ç Kara, O. Abdulkadir, T. Ersin, Ç. Ender. Effects of Supplementary Nutrition in Awassi Ewes on Sexual Behaviors and Reproductive Traits. Journal of Biology and Environment Science 2010: Vol 4(10), 15-21.

[17] F. El Hag, B. Fadlalla, H. Mukhtar. Some production characteristics of Sudan Desert sheep under range condition in North Kordofan Sudan. Tropical Animal Health and Production 2001: Vol: 33: 229 239. DOI: 10.1023/A: $1010366805607 \cdot$ Source: PubMed.

[18] M. Ali, M. Abdella, H. Elimam, M. Sulieman, F. El-Hag, N. Eshag, and B. Jadalla. Pre-weaning Body Measurements and Performance of Desert Sheep (Tribal Subtypes Hamari and Kabashi) Lambs of Kordofan Region Sudan. Malaysian Journal of Animal Science 2014, Vol: 17(1): 35-45. Record Number: 20143414440.

[19] H. Abou. Some Production traits of Sudan indigenous sheep under Shambat farm condition. M Sc., Faculty of Animal Production, University of Khartoum, 1980.

[20] A. Idris The effect of feed supplementation strategies on productive and reproductive performance of Desert sheep in rangeland of Kordofan. Ph. D, Faculty of Animal Production, University of Khartoum, 2008.

[21] F. El Hag, M. Ahamed, A. Salih, K. Mohammed, B. Fadlalla.A. Ibnoaf, and M. Ahmed. Supplementary feeding to improve Desert sheep Productivity under dry land farming. Tropical Science 2007, Vol: 46 (4): 122-129. doi: 10.1002/ts.188.H. Singh, E. Moore Livestock and poultry production. $2^{\text {nd }}$ ed., prentice- Hall of India, New Delhi. 1982 pp 23-235.

[22] F. Begum, F. Azizunnesa, S. Golam, Y. Farida. Reproductive Performances of Indigenous Ewes in Bangladesh, Journal of Agriculture and Veterinary Science 2014 Vol: (7) PP 64-72. E-ISSN: 2319-2380, p-ISSN: 2319-2372. Volume 7, Issue 5 Ver. I (May. 2014), PP 64-72 www.iosrjournals.org.

[23] J. Jadalla, D. Mekki, S. Bukhari, N. Eshag. Effects of supplementation of the natural grazing with Roselle seeds on dry mater intake and performance of Desert sheep lambs in West Kordofan Sudan. African Journal of Animal and Biomedical Science 2014: Vol: 8(1): 11-16. doi: 10.3923/ajas.2012.240.248.

[24] F. El Hag, B. Fadlalla, M. El Madih. Effect of strategic Supplementary feeding on ewe Productivity under range condition in north Kordofan. Small Ruminant Research 1998: Vol: 30:67- 71. doi P II S 0921 - 4488 (98)000080-7.

[25] M. Ali,O. Abdella, E. Elimam, H. Sulieman, M. Tibin. E. Neama, and B. Jadalla. The effect of feeding groundnut hay and concentrates on some carcass characteristics of Sudanese Desert lambs (tribal subtypes Hamari and Kabashi) in North Kordofan State, Sudan. Greener Journal of Agriculture Science 2015, Vol. 5 (7), pp. 233-239. DOI: http://doi.org/10.15580/GJAS.2015.7.081214325.

[26] A. Lutfi. The performance of Desert sheep fed protein and energy from different sources. M Sc, Faculty of Animal Production, University of Khartoum, 1983.

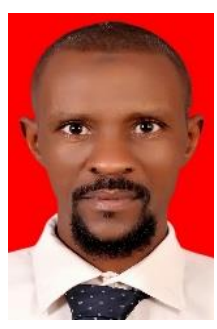

Omer Mohammed Bushara was born on 1st July, 1974 in Sudan. He has Master Degree (2011) and Ph. D. (2016) in Meat production from Faculty of Animal production in Khartoum University. He is currently assistant professor in Department of meat production, Faculty of Animal Production, Alkhuway, West Kordofan University. 